\title{
Identification of parathyroid hormone-related protein-derived peptides immunogenic in human histocompatibility leukocyte
} antigen-A24 ${ }^{+}$prostate cancer patients

\author{
A Yao', M Harada*,', S Matsueda', Y Ishihara', H Shomura', M Noguchi', K Matsuoka', I Hara ${ }^{3}$, S Kamidono ${ }^{3}$ \\ and $\mathrm{K}$ Itoh'
}

'Department of Immunology, Kurume University School of Medicine, Fukuoka, Japan; ' ${ }^{2}$ Department of Urology, Kurume University School of Medicine, Fukuoka, Japan; ${ }^{3}$ Division of Urology, Department of Organs Therapeutics, Faculty of Medicine, Kobe University Graduate School of Medicine, Hyogo, Japan

\begin{abstract}
Parathyroid hormone-related protein (PTHrP) is a key factor in the development of bone metastases, which are a major barrier in treating prostate cancer patients. In this study, we attempted to identify PTHrP-derived peptides immunogenic in human histocompatibility leukocyte antigen (HLA)-A24 ${ }^{+}$prostate cancer patients. Among four different PTHrP peptides carrying the HLAA24 binding motif, both the $\mathrm{PTHrP} 36-44$ and $\mathrm{PTHrP} 102-111$ peptides efficiently induced peptide-specific cytotoxic $\mathrm{T}$ lymphocytes from peripheral blood mononuclear cells (PBMCs) of $\mathrm{HLA}-\mathrm{A} 24^{+}$prostate cancer patients. Peptide-stimulated PBMCs showed cytotoxicity against prostate cancer cells in an HLA-A24-restricted manner. Experiments using antibodies and cold inhibition targets confirmed that their cytotoxicity was dependent on PTHrP peptide-specific and CD8 ${ }^{+} \mathrm{T}$ cells. Immunoglobulin $\mathrm{G}$ reactive to the PTHrP ${ }_{102-111}$ or $\mathrm{PTHrP}_{110-119}$ peptide was frequently detected in the plasma of prostate cancer patients, suggesting that the PTHrP ${ }_{102-111}$ peptide is able to elicit cellular and humoral immune responses in cancer patients. These results indicate that the PTHrP could be a promising target molecule for specific immunotherapy of HLA-A24 ${ }^{+}$prostate cancer patients with metastases. British Journal of Cancer (2004) 91, 287-296. doi: I 0.1038/sj.bjc.660I960 www.bjcancer.com

Published online 15 June 2004

(c) 2004 Cancer Research UK
\end{abstract}

Keywords: prostate cancer; parathyroid hormone-related protein (PTHrP); cytotoxic T lymphocyte; peptide; HLA-A24

Prostate cancer is one of the most common cancers among elderly men (Greenlee et al, 2000). Prostate cancer frequently metastasises to bone. Androgen withdrawal therapy has been applied for patients with bone metastases. Although hormone therapy can temporarily inhibit the progress of the disease in these patients, a progression to hormone-refractory prostate cancer inevitably occurs in most cases. Therefore, the development of new therapeutic modalities is needed.

Recent advances in tumour immunology have allowed us to identify the genes encoding human cancer-related antigens, and the epitopes, which are recognized by cytotoxic $\mathrm{T}$ lymphocytes (CTLs), in patients with various types of cancers (Boon et al, 1997; Rosenberg, 1999; Renkvist et al, 2001). The identified tumour antigens and their peptides have been applied for specific immunotherapy (Nestle et al, 1998; Rosenberg et al, 1998; Marchand et al, 1999). In the case of prostate cancer, tissuespecific antigens, which are expressed in the normal prostate, can also be target molecules for specific immunotherapy for patients

\footnotetext{
* Correspondence: Dr M Harada, Department of Immunology, Kurume University School of Medicine, 67 Asahi-machi, Kurume, Fukuoka 83000 I I, Japan; E-mail: haramamo@med.kurume-u.ac.jp

Received 8 December 2003; revised 6 April 2004; accepted 27 April 2004; published online 15 June 2004
}

with this disease. Immunotherapy targeting prostate-specific antigens or prostate-specific membrane antigens has been carried out, and antitumour effects have been observed in limited cases (Murphy et al, 1996, 1999; Tjoa et al, 1998; Small et al, 2000; Gulley et al, 2002).

Parathyroid hormone-related protein (PTHrP) is an autocrine or paracrine factor that binds to receptors on osteoblasts, and stimulates bone formation and reabsorption. Parathyroid hormone-related protein has limited homology with $\mathrm{PTH}$ at its $\mathrm{NH} 2$ terminus, and can bind to the same receptor as PTH, resulting in similar biological activity (Suva et al, 1987; Juppner et al, 1991). Parathyroid hormone-related protein plays a variety of physiological roles, including calcium transport, keratinocyte differentiation, smooth muscle relaxation, and cartilage development (Philbrick et al, 1996). In parathyroid cells, a high extracellular calcium concentration inhibits parathyroid hormone (PTH) secretion and the proliferation of parathyroid cells as a result of negative feedback regulation, whereas it evokes further PTHrP secretion and promotes worsening bone resorption (Sanders et al, 2001). Therefore, PTHrP has been considered to be responsible for the hypercalcemia associated with malignancy (Guise, 1997). In addition, prostate cancers have been reported to produce PTHrP (Francini et al, 2002). These lines of evidence suggest that PTHrP could be a promising target molecule for the immunotherapy of prostate cancer patients with bone metastases. In this study, we 
attempted to identify new, PTHrP-derived peptides that are immunogenic in HLA-A $24^{+}$prostate cancer patients.

\section{MATERIALS AND METHODS}

\section{Patients}

Informed consent was obtained from all of the HLA-A24 ${ }^{+}$prostate cancer patients and HLA-A24 ${ }^{+}$healthy volunteers who were enrolled in this study. None of the participants were infected with HIV. In total, $20 \mathrm{ml}$ of peripheral blood was obtained, and the PBMCs were prepared by Ficoll-Conray density gradient centrifugation. The expression of HLA-A24 molecules on the PBMCs of the cancer patients and healthy donors was determined by flow cytometry.

\section{Cell lines}

C1R-A24 is an HLA-A*2402-expressing subline of C1R lymphoma (Dr M Takiguchi, Kumamoto University, Japan). LNCaP is an HLA-A24 negative prostate cancer cell line. To establish LNCaP cells that stably express HLA-A24 molecules (designated as LNCaP-A24), an HLA-A ${ }^{\star} 2402$ gene was inserted into a pcDNA3.1/Hygro vector (Invitrogen, CA, USA), and electroporated into the LNCaP cell line (ATCC, Manassas, VA, USA), and selection was carried out with hygromycin B (Invitrogen) at a dose of $170 \mu \mathrm{g} \mathrm{ml}^{-1}$. All cell lines were maintained in RPMI-1640 medium (Gibco BRL, Grand Island, NY, USA) supplemented with $10 \%$ FCS.

\section{Peptides}

Four PTHrP-derived peptides (listed in Table 1) were prepared based on the HLA-A24 binding motif (Parker et al, 1994; Rammensee et al, 1995). All peptides were of $>90 \%$ purity and were purchased from Biologica Co., Nagoya, Japan. Influenza (Flu) virus-derived (RFYIQMCYEL), EBV-derived (TYGPVFMCL), and HIV-derived peptides (RYLRQQLLGI) with the HLA-A24 binding motif were used as controls. All peptides were dissolved with DMSO at a dose of $10 \mathrm{mg} \mathrm{ml}^{-1}$.

\section{Assay for peptide-specific CTLs in PBMCs}

The assay for the detection of peptide-specific CTLs in PBMCs was performed according to a previously reported method (Hida et al, 2002). In brief, PBMCs $\left(1 \times 10^{5}\right.$ cells per well $)$ were incubated with $10 \mu \mathrm{g} \mathrm{ml}^{-1}$ of each peptide in a U-bottom-type 96-well microculture plate (Nunc, Roskilde, Denmark) at a volume of $200 \mu \mathrm{l}$ of culture medium. The culture medium consisted of $45 \%$ RPMI$1640,45 \%$ AIM-V medium (Gibco BRL), $10 \%$ FCS, $100 \mathrm{U} \mathrm{ml}^{-1}$ of IL-2, and 0.1 mM MEM nonessential amino-acid solution (Gibco, $\mathrm{BRL})$. Half of the culture medium was removed and replaced with new medium containing a corresponding peptide $\left(20 \mu \mathrm{g} \mathrm{ml}^{-1}\right)$ every 3 days. On the 15 th day of culture, the cultured cells were separated into four wells; two wells were used for the PTHrP peptide-pulsed C1R-A24 cells, and the other two wells were used for the HIV peptide-pulsed C1R-A24 cells. After an 18-h incubation period, the supernatants were collected, and the level of IFN- $\gamma$ was determined by ELISA (limit of sensitivity: $10 \mathrm{pg} \mathrm{ml}^{-1}$ ).

Table I Reactivity of PTHrP peptide-stimulated PBMCs from HLA-A24+ healthy donors and prostate cancer patients

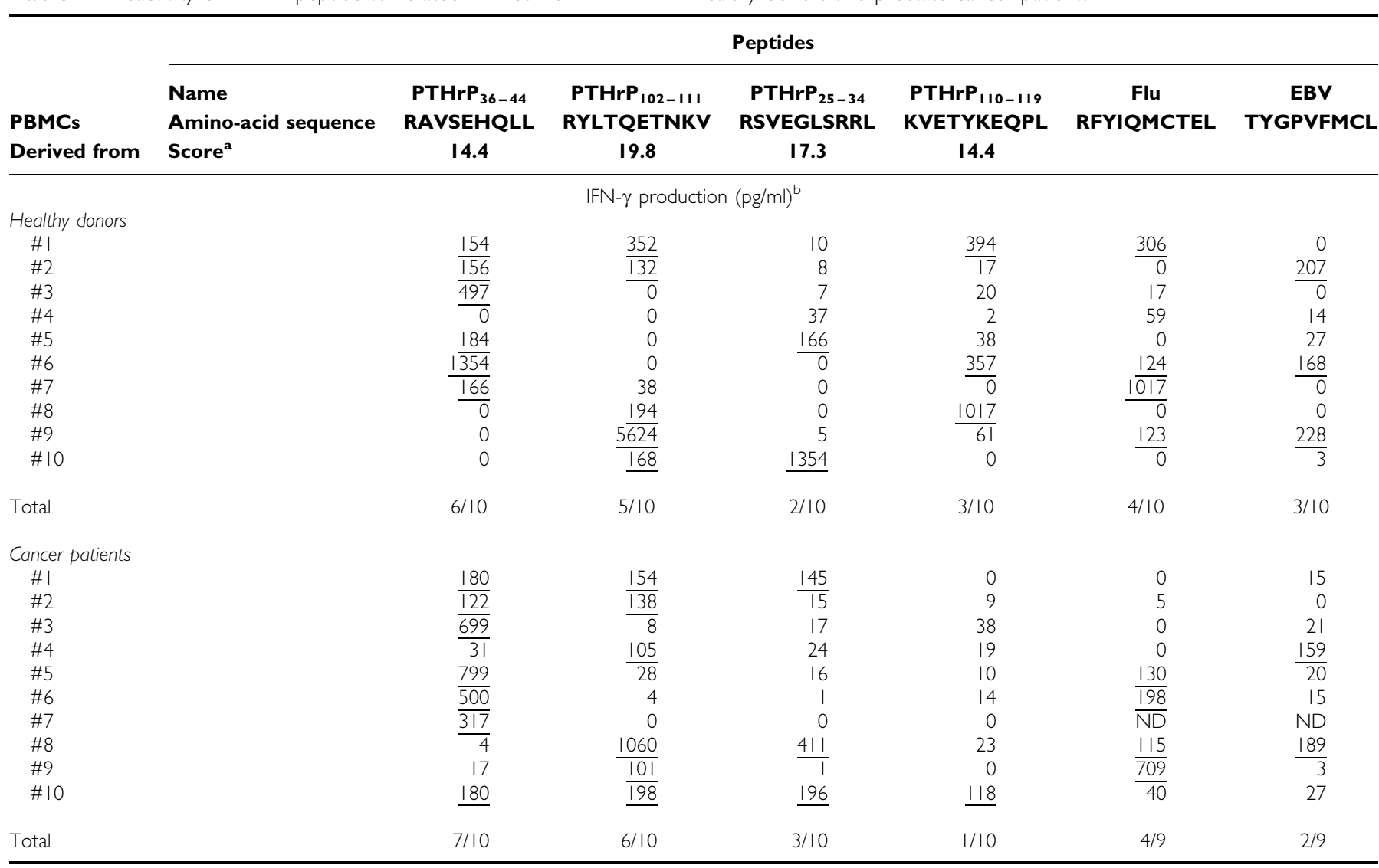

${ }^{a}$ The score represents the estimated half-time of dissociation of the PTHrP peptides binding to HLA-A24 molecules. ${ }^{\text {b}}$ The PBMCs of HLA-A24 ${ }^{+}$healthy donors and prostate cancer patients were stimulated in vitro with the indicated PTHrP peptide, as described in Material and Methods. On the I5th day, the cultured PBMCs were tested for their reactivity to CIR-A24 cells, which were prepulsed with the corresponding peptide or the HIV peptide. The values represent the mean of two wells, and the background IFN- $\gamma$ production in response to the HIV peptide was subtracted. Significant values $(P<0.05$ by two-tailed Student's $t$-test $)$ are underlined. ND $=$ not done. 


\section{Cytotoxicity assay}

After in vitro stimulation with the PTHrP peptides, the peptidestimulated PBMCs were additionally cultured with $100 \mathrm{U} \mathrm{ml}^{-1} \mathrm{IL}-2$ for approximately 10 days, in order to obtain a sufficient number of cells to carry out a cytotoxicity assay. These cells were then tested for cytotoxicity against both LNCaP and LNCaP-A24 by a 6 -h ${ }^{51} \mathrm{Cr}$-release assay. A total of $2000{ }^{51} \mathrm{Cr}$-labelled cells per well were cultured with effector cells in 96-round-well plates at the indicated effector/target ratios. In some experiments, either anti-HLA class I (W6/32: mouse IgG2a), anti-HLA-DR (L243: mouse IgG2a), anti-CD4 (NU-TH/I: mouse IgG1), anti-CD8 (NUTS/C: mouse IgG2a), or anti-CD14 (H14: mouse IgG2a) mAb was added to the wells at a dose of $20 \mu \mathrm{g} \mathrm{ml}^{-1}$ at the initiation of the assay.

\section{Cold inhibition assay}

The specificity of the PTHrP peptide-stimulated CTLs was confirmed by a cold inhibition assay. In brief, ${ }^{51} \mathrm{Cr}$-labelled target cells $\left(2 \times 10^{3}\right.$ cells per well $)$ were cultured with the CTLs $\left(4 \times 10^{4}\right.$ cells per well) in 96-round-well plates with $2 \times 10^{4}$ cold target cells. C1R-A24 cells, which were prepulsed with either the HIV peptide or a corresponding PTHrP peptide, were used as cold targets.

\section{Detection of peptide-specific IgG}

The peptide-specific IgG levels in the plasma were measured by ELISA, as previously reported (Nakatsura et al, 2002; Ohkouchi et al, 2002). In brief, peptide ( $20 \mu \mathrm{g}$ per well)-immobilised plates were blocked with Block Ace (Yukijirushi, Tokyo, Japan) and washed with $0.05 \%$ Tween-20-PBS, after which $100 \mu \mathrm{l}$ per well of plasma sample diluted with $0.05 \%$ Tween-20-Block Ace was added to the plate. After a 2 -h incubation at $37^{\circ} \mathrm{C}$, the plates were washed and further incubated for 2-h with a 1:1000-diluted rabbit antihuman IgG ( $\gamma$-chain-specific) (DAKO, Glostrup, Denmark). The plates were washed, and then $100 \mu \mathrm{l}$ of $1: 100$-diluted goat antirabbit IgG-conjugated horseradish peroxidase (EnVision, DAKO) was added to each well, and the plates were then incubated at room temperature for $40 \mathrm{~min}$. After the plates were washed once, $100 \mu \mathrm{l}$ per well of tetramethyl benzidine substrate solution (KPL, Guildford, UK) was added, and the reaction was stopped by the addition of $1 \mathrm{~m}$ phosphoric acid. The values are shown as optical density (OD) units $\mathrm{ml}^{-1}$. IgG reactive to a corresponding PTHrP peptide was judged to be positive when the difference of the OD in $1: 100$-diluted plasma exceeded 0.05 . To confirm the specificity of IgG to the indicated PTHrP peptide, sample plasma was cultured with plates coated with either the corresponding PTHrP peptide or an irrelevant PTHrP peptide. Thereafter, the levels of PTHrP peptide-specific IgG in the resulting supernatant were determined by ELISA.

\section{Statistics}

The statistical significance of the data was determined using a twotailed Student's $t$-test. A $P$-value of less than 0.05 was considered to be statistically significant.

\section{RESULTS}

Induction of PTHrP peptide-specific CTLs from HLA$\mathrm{A}^{2} 4^{+}$healthy donors and prostate cancer patients

First, four PTHrP-derived peptides were prepared based on their binding affinity to HLA-A24 molecules (Parker et al, 1994; Rammensee et al, 1995) (Table 1). Although the $\mathrm{PTHrP}_{1-36}$ peptide is a propeptide (Suva et al, 1987; Juppner et al, 1991), the
$\mathrm{PTHrP}_{25-34}$ peptide was included. With regard to the difference in amino acids, three amino acids were found to differ between the $\mathrm{PTHrP}_{36-44}$ peptide and $\mathrm{PTH}$, and all of the amino acids were found to differ between the other three PTHrP peptides and PTH. Next, to investigate the immunogenicity of these four PTHrP peptides, the PBMCs of 10 HLA-A24 ${ }^{+}$healthy donors and 10 HLA-A $24^{+}$prostate cancer patients were stimulated with each of four PTHrP peptides, and were then examined for their IFN- $\gamma$ production in response to C1R-A24 cells, which were prepulsed with either a corresponding PTHrP peptide or the HIV peptide (Table 1). Flu- and BEV-derived peptides were used as controls. The assay was carried out in quadruplicate. The cultured cells in one well were separated into four wells. Two wells were used for the PTHrP peptide-pulsed C1R-A24 cells, and the other two wells for the HIV peptide-pulsed C1R-A24 cells. The background IFN- $\gamma$ production in response to the HIV peptide was subtracted, and the results that showed the best response are shown in Table 1. The successful induction of peptide-specific CTLs was judged to be positive when significant values $(P<0.05$ by two tailed Student's $t$ test) were observed. The results showed that the $\mathrm{PTHrP}_{36-44}$, $\mathrm{PTHrP}_{102-111}, \mathrm{PTHrP}_{25-34}$, and $\mathrm{PTHrP}_{110-119}$ peptides induced peptide-specific CTLs in six, five, two, and three of 10 HLA-A24 ${ }^{+}$ healthy donors, respectively. These PTHrP peptides also induced peptide-specific CTLs in seven, six, three, and one of 10 HLA$\mathrm{A}_{2}{ }^{+}$prostate cancer patients, respectively. The net IFN- $\gamma$ production of the cases with 10 HLA-A24 ${ }^{+}$prostate cancer patients in response to the corresponding PTHrP peptide or the HIV peptide are shown in Figure 1. In total, these findings indicate that both the $\mathrm{PTHrP}_{36-44}$ and $\mathrm{PTHrP}_{102-111}$ peptides are promising candidates to generate peptide-specific CTLs from HLA-A $24^{+}$ prostate cancer patients.

\section{Induction of prostate cancer-reactive CTLs using PTHrP $_{36-44}$ and PTHrP $102-111$ peptides}

In order to investigate the HLA-A24-restricted and prostate cancer-reactive cytotoxicity of peptide-stimulated PBMCs, we prepared an HLA-A24-expressing LNCaP cell line, which we designated LNCaP-A24 (Figure 2). LNCaP has previously been reported to produce PTHrP (Francini et al, 2002). A parental LNCaP cell line was negative for the cell surface expression of HLA-A24 molecules, whereas the LNCaP-A24 cell line expressed HLA-A24 molecules on their cell surface. It was then determined whether PBMCs stimulated by either the $\mathrm{PTHrP}_{36-44}$ or $\mathrm{PTHrP}_{102}$ 111 peptide could induce prostate cancer-reactive CTLs from HLA$\mathrm{A} 24^{+}$healthy donors and prostate cancer patients. PBMCs from HLA-A $24^{+}$healthy donors and cancer patients were repeatedly stimulated with the indicated PTHrP peptide, based on the culture protocol described in Materials and Methods. After confirming that these peptide-stimulated cells could produce IFN- $\gamma$ in response to PTHrP peptide-pulsed C1R-A24 cells, the peptidestimulated PBMCs were examined for their cytotoxicity against three targets. It was found that the PTHrP peptide-stimulated PBMCs from $\mathrm{HD} \# 2$, $\mathrm{Pt} \# 1$, and $\mathrm{Pt} \# 2$ produced higher levels of IFN- $\gamma$ in response to the corresponding PTHrP peptide-pulsed C1R-A24 cells than to the HIV peptide-pulsed C1R-A24 cells (Figure 3A). These peptide-stimulated PBMCs also showed higher levels of cytotoxicity against the LNCaP-A24 cell line than against the LNCaP line and HLA-A24 ${ }^{+}$PHA-induced T cell blasts (Figure 3B). In addition, their cytotoxicity against LNCaP-A24 was significantly inhibited by the addition of anti-HLA-class I and anti-CD8 $\mathrm{mAbs}$, but not by the addition of other anti-HLA-class II, anti-CD4, or anti-CD14 mAbs (Figure 4A). Furthermore, their cytotoxicity against the LNCaP-A24 cell line was significantly suppressed by the addition of the corresponding PTHrP peptide-pulsed C1R-A24 cells, as a cold target, but this suppression was not observed with the addition of HIV peptide-pulsed C1R-A24 cells (Figure 4B). In 

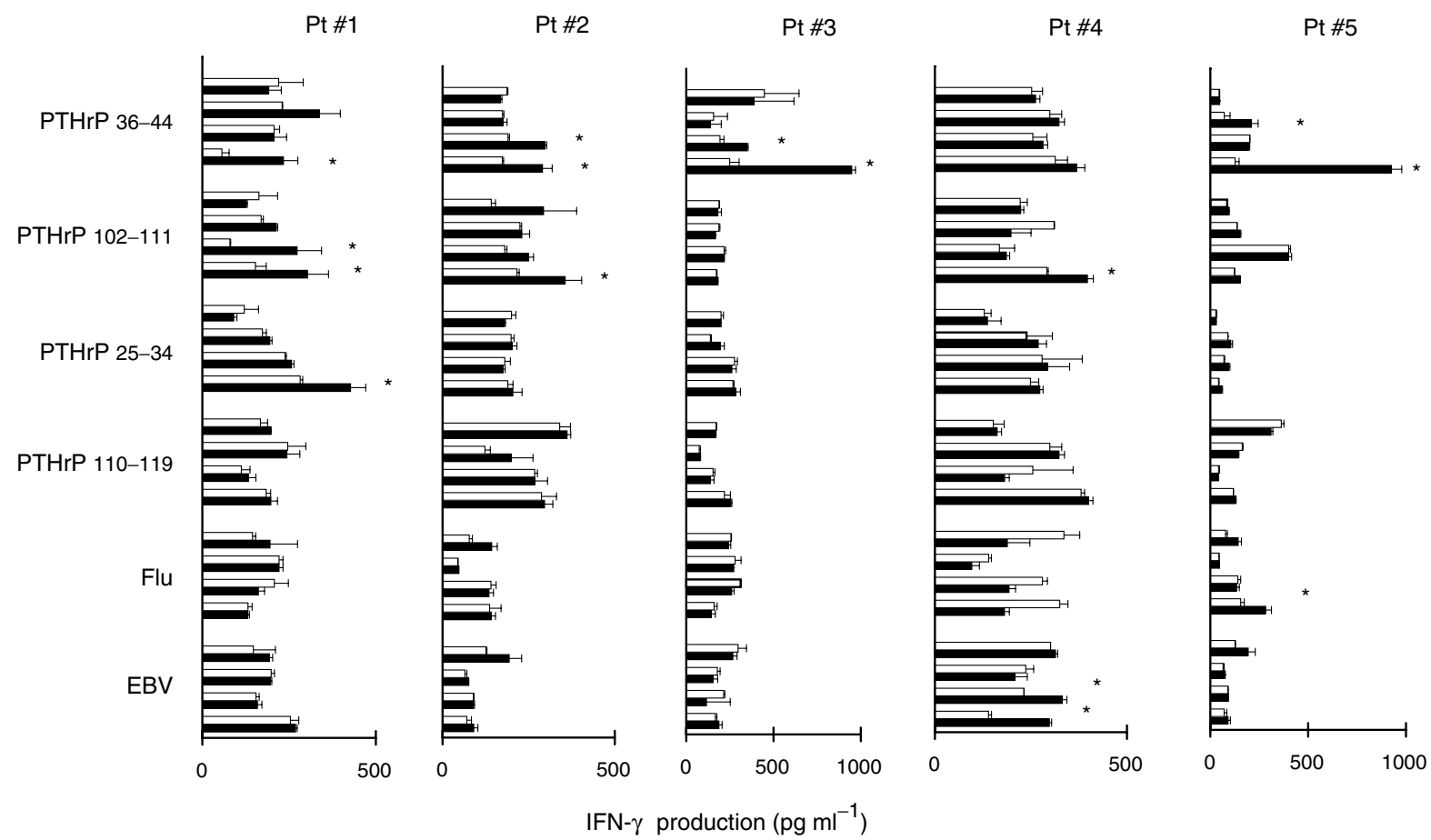

Pt \#6

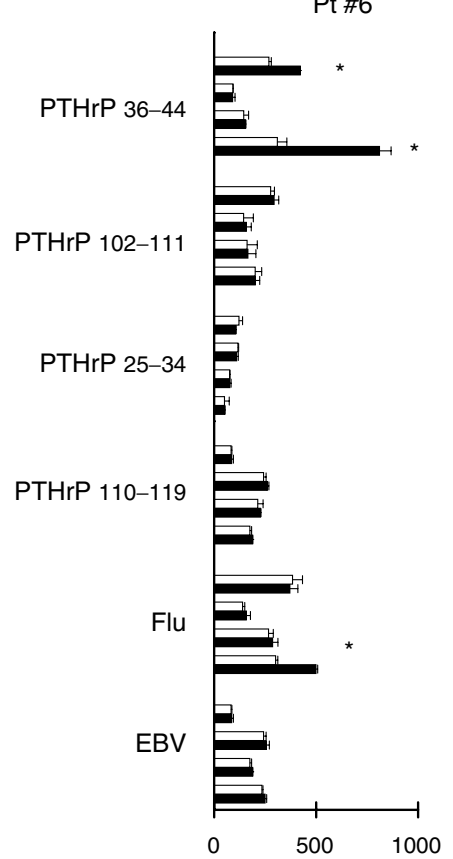

Pt \#7

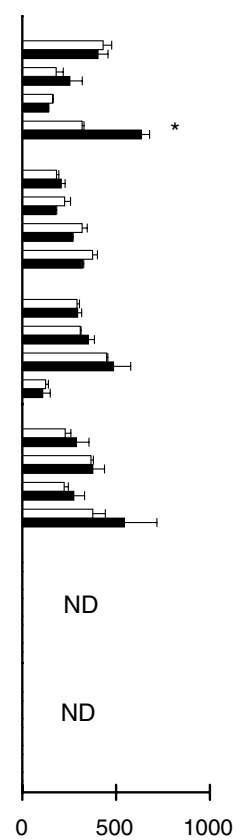

Pt \#8

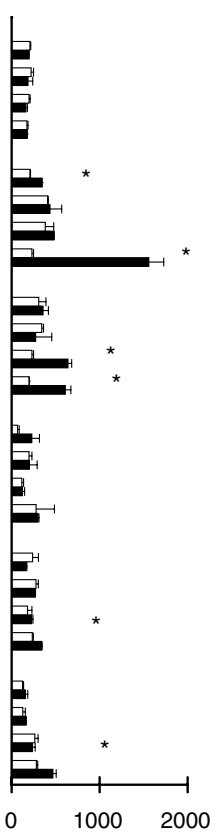

Pt \#9
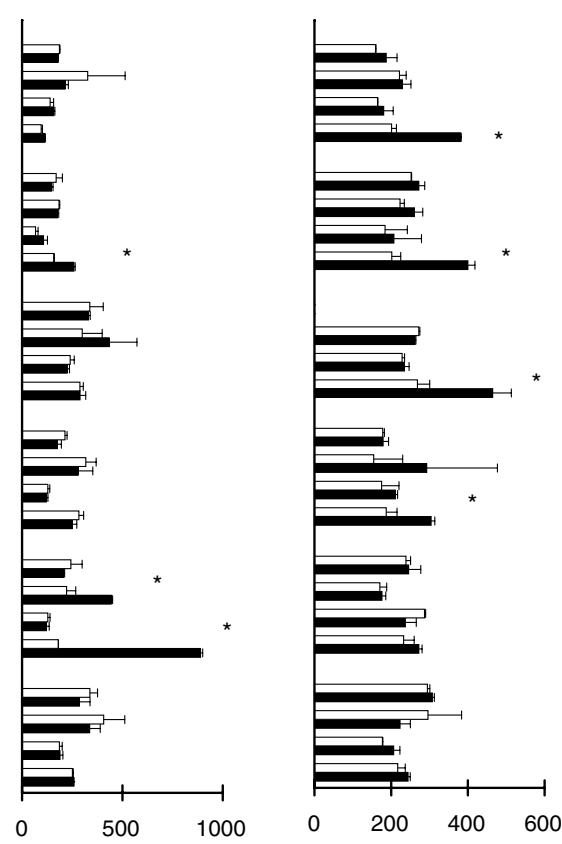

IFN- $\gamma$ production $\left(\mathrm{pg} \mathrm{ml}^{-1}\right)$

Figure I Induction of PTHrP peptide-specific CTLs from the PBMCs of HLA-A24 ${ }^{+}$prostate cancer patients. PBMCs from $10 \mathrm{HLA}^{-\mathrm{A} 24^{+}}{ }^{+}$prostate cancer patients were stimulated in vitro with the PTHrP peptides indicated, as described in Materials and Methods. On the 15 th day, the peptide-stimulated cells were cultured with CIR-A24 cells, which were prepulsed with an HIV peptide (open bar) and the indicated PTHrP peptide (closed bar) for I 8-h. The levels of IFN- $\gamma$ in the supernatants were then determined by ELISA. *P $<0.05$ was considered statistically significant. 

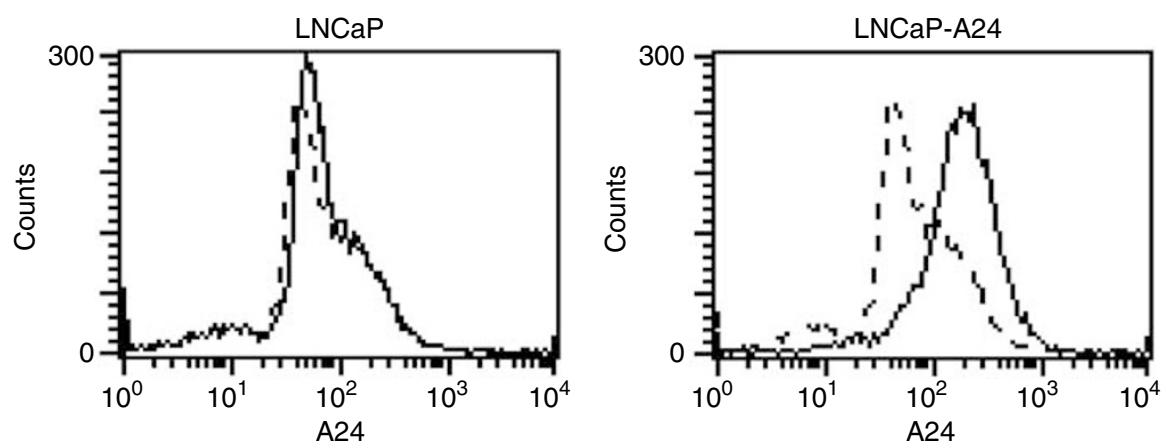

Figure 2 An HLA-A24-expressing LNCaP cell line. Flow cytometric analysis was performed on the LNCaP and LNCaP-A24 cells. These cells were stained with anti-HLA-A24 mAb, followed by FITC-conjugated anti-mouse lgG mAb. The dotted lines represent staining without the first $m A b$.

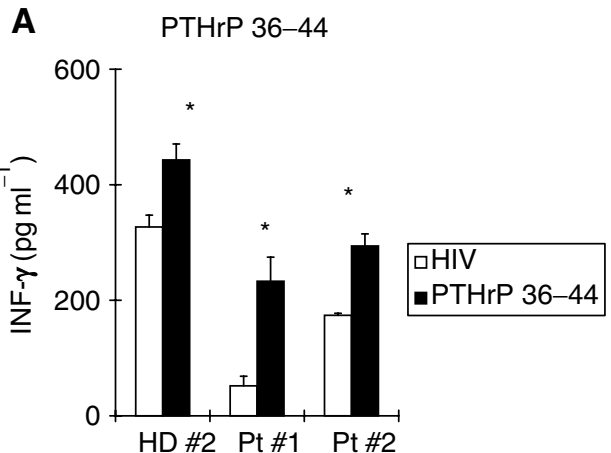

B

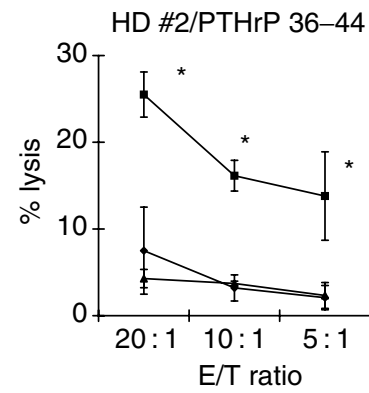

HD \#2/PTHrP 102-111

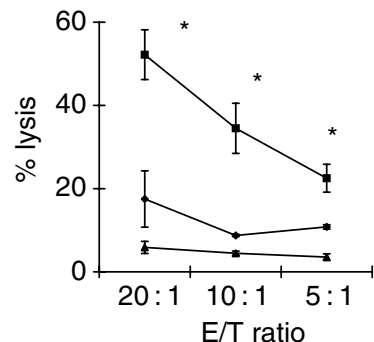

Pt \#1/PTHrP 36-44

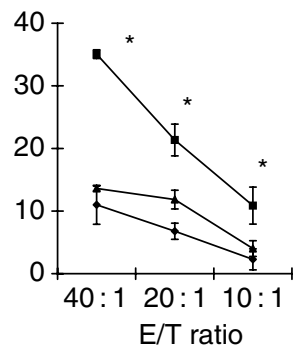

Pt \#1/PTHrP 102-111

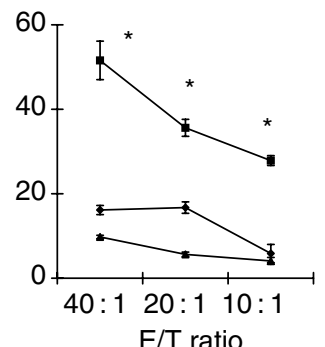

PTHrP 102-111

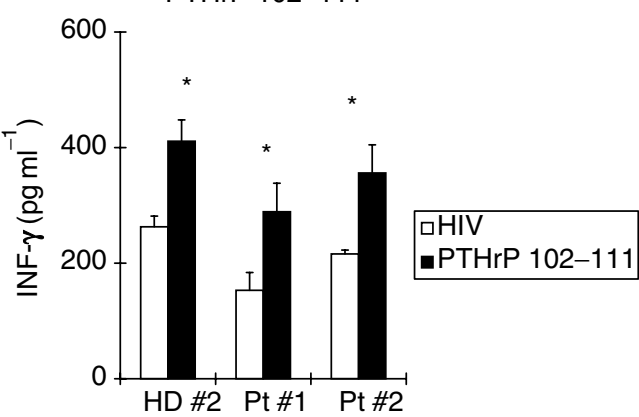

Pt \#2/PTHrP 36-44

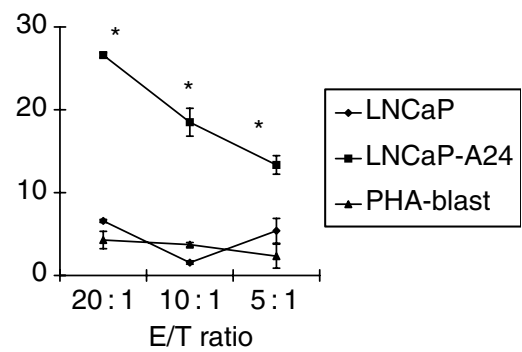

Pt \#2/PTHrP 102-111

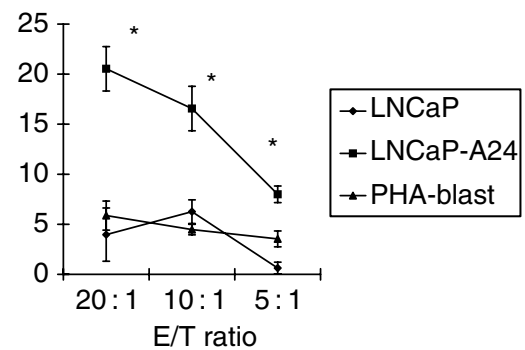

Figure 3 Induction of HLA-A24-restricted and prostate cancer-reactive CTLs from the PBMCs of healthy donors and cancer patients. (A) PBMCs from one HLA-A24 ${ }^{+}$healthy donor (HD \#2) and from two HLA-A24 $4^{+}$prostate cancer patients (Pt \#I and Pt \#2) were stimulated in vitro with the indicated PTHrP peptides, as described in Materials and Methods. On the I5th day, half of the cultured cells were harvested, pooled from four wells, and cultured with CIR-A24 cells, which were prepulsed with an HIV peptide (open symbol) and the indicated PTHrP peptide (closed symbol) for I8-h. The levels of IFN- $\gamma$ in the supernatants were then determined by ELISA. (B) Thereafter, these cells were examined for their cytotoxicity against the LNCaP cells (HLA-A24), LNCaP-A24 cells (HLA-A24 ${ }^{+}$), and PHA-blastoid T cells $\left(\mathrm{HLA}-\mathrm{A} 24^{+}\right)$. A 6-h ${ }^{51} \mathrm{Cr}$-release assay was performed. Values represent the mean of triplicate assays. $* P<0.05$ was considered statistically significant.

addition, we observed that these PTHrP peptide-stimulated PBMCs from cancer patients showed cytotoxicity against another prostate cancer cells PC-93-A24, stably expressed the HLA-A24 molecules and produced PTHrP (data not shown). These results indicate that both the $\mathrm{PTHrP}_{36-44}$ and $\mathrm{PTHrP}_{102-111}$ peptides have the potential to induce prostate cancer-reactive CTLs from HLA-A24 ${ }^{+}$prostate 
A

Antibody HD \#2/PTHrp 36-44
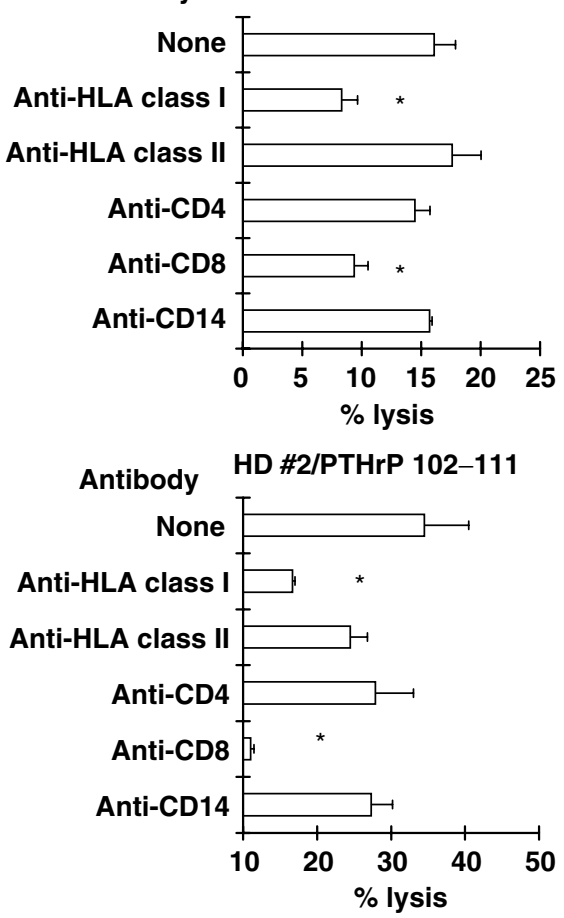

Pt \#1/PTHrP 36-44

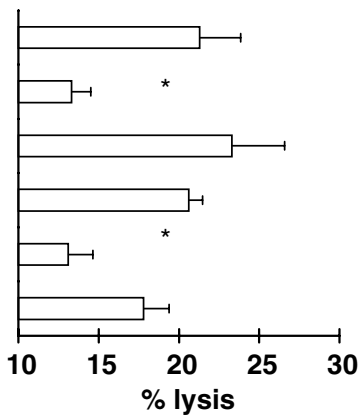

Pt \# 1/PTHrP 102-111

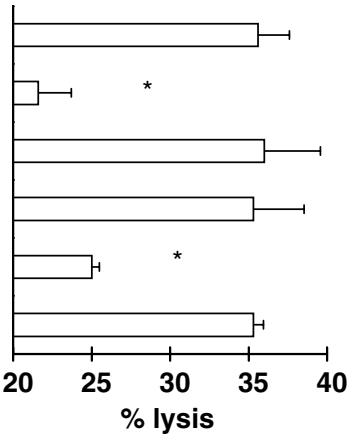

Pt \#2/PTHrP 36-44

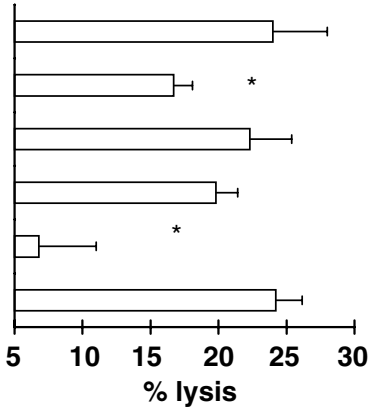

Pt \#2/PTHrP 102-111

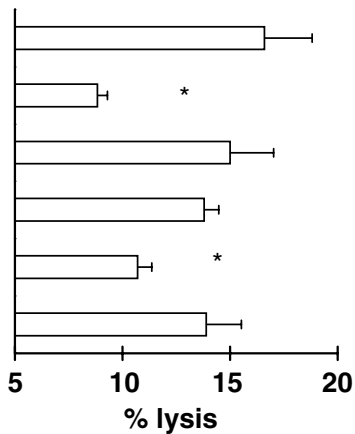

B

HD \#2/PTHrP 36-44

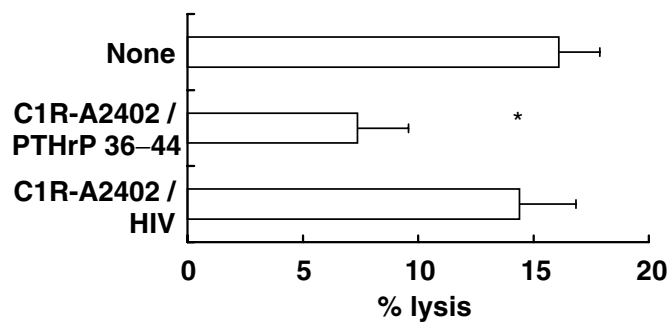

HD \#2/PTHrP 102-111

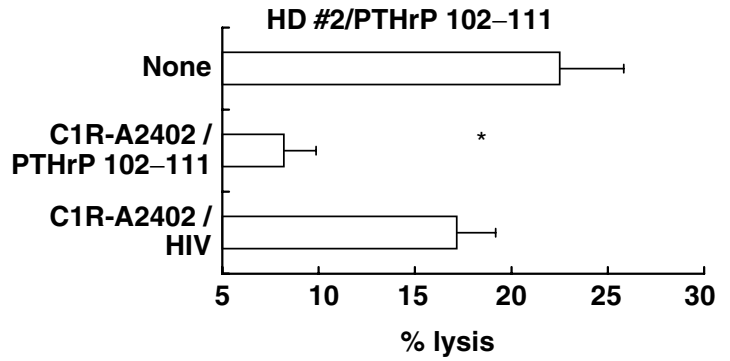

Pt \#1/PTHrP 36-44

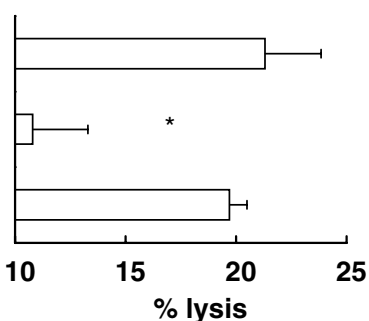

Pt \#1/PTHrP 102-111

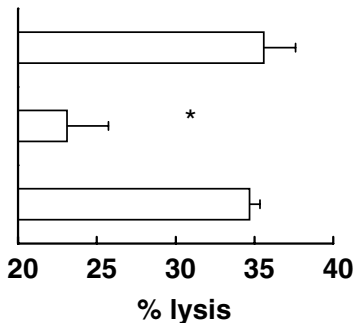

Pt \#2/PTHrP 36-44

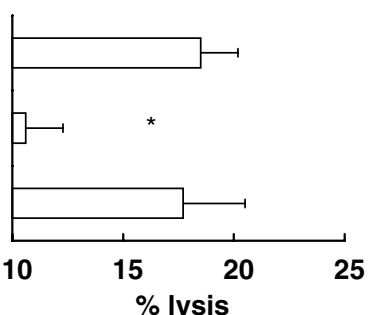

Pt \#2/PTHrP 102-111

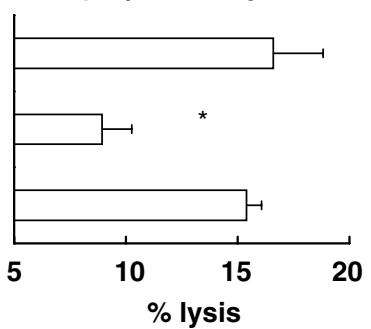

Figure $4 \mathrm{CD}^{+}$T-cell-dependent and PTHrP peptide-specific cytotoxicity against LNCaP-A24 cells. (A) The PTHrP peptide-stimulated PBMCs, described in Figure 2, were examined for their cytotoxicity against the LNCaP-A24 cell line, with or without anti-HLA class I, anti-HLA class II, anti-CD4, antiCD8, or anti-CD 4 mAb at a dose of $20 \mu \mathrm{g} \mathrm{ml}^{-1}$. The values represent the mean of triplicate assays. * $P<0.05$ was considered statistically significant. (B) The cytotoxicity against the LNCaP-A24 cell line $\left(2 \times 10^{3}\right.$ cells per well) was also examined in the presence of unlabelled CIR-A24 cells $\left(2 \times 10^{4}\right.$ cells per well) which were prepulsed with the HIV peptide or a corresponding PTHrP peptide. The values represent the mean of triplicate assays. $* P<0.05$ was considered statistically significant.

cancer patients, and that their cytotoxicity against prostate cancer was dependent on PTHrP peptide-specific CD8 ${ }^{+}$T cells.

\section{Detection of IgG reactive to the PTHrP peptides}

We previously reported that IgGs reactive to CTL epitope peptides were detected in healthy donors and cancer patients (Nakatsura et al, 2002; Ohkouchi et al, 2002). IgGs reactive to prostate-related antigens were also detected in healthy donors and prostate cancer patients (Harada et al, 2003a; Kobayashi et al, 2003; Matsueda et al, 2004) Therefore, we attempted to determine whether IgG reactive to four PTHrP-derived peptides could be detected in the plasma of cancer patients and healthy donors. The result was that IgG reactive to either the $\mathrm{PTHrP}_{102-111}$ or the $\mathrm{PTHrP}_{109-119}$ peptide 
Table 2 IgG reactive to the PTHrP peptides in plasma of HLA-A24 $4^{+}$healthy donors and prostate cancer patients

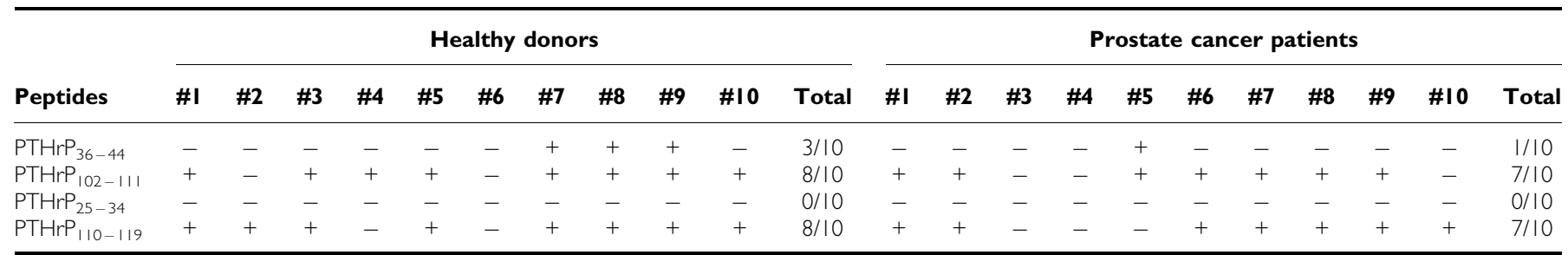

$\lg \mathrm{G}$ reactive to the corresponding peptide was judged to be positive when the difference in the OD in I: I00-diluted plasma exceeded 0.05. The cutoff level (OD: 0.05) was determined based on the levels of anti-HIV peptide IgG in HIV-negative healthy donors.

was detected in eight of 10 healthy donors and in seven of 10 prostate cancers (Table 2). Representative results are in Figure 5A. However, IgG reactive to the $\mathrm{PTHrP}_{36-44}$ peptide was detected in three of 10 healthy donors and one of 10 prostate cancer patients, respectively. No IgG reactive to $\mathrm{PTHrP}_{25-34}$ was detected in any of the healthy donors or cancer patients. The levels of PTHrP peptide-specific IgG were significantly diminished by culturing the plasma in the corresponding PTHrP peptide-coated wells (Figure 5B). This peptide-specific absorption demonstrated the validity of the present assay system.

\section{DISCUSSION}

Prostate cancer appears to be a good target for the development of specific immunotherapies (Harada et al, 2003b). In recent years, our group has attempted to identify epitope peptides derived from prostate-related antigens that would be able to generate prostate cancer-reactive CTLs from prostate cancer patients (Inoue et al, 2001; Kobayashi et al, 2003; Harada et al, 2003a; Matsueda et al, 2004). However, one major obstacle encountered when treating prostate cancer patients is the treatment of bone metastases, as prostate cancer frequently metastasises to the bone tissue. Therefore, we undertook the present study to identify epitope peptides that could potentially be suitable for specific the immunotherapy of $\mathrm{HLA}-\mathrm{A} 24^{+}$prostate cancer patients with metastases.

PTHrP is known to be a key agent in the development of bone metastasis in cases of prostate cancer, and prostate cancer cells has been reported to produce PTHrP (Francini et al, 2002). These lines of evidence indicate that PTHrP could be a good target for the development of specific immunotherapies against metastatic prostate cancer. Indeed, $\mathrm{PTHrP}_{59-68}$ and $\mathrm{PTHrP}_{165-173}$ peptides have been reported to be candidates for such specific immunotherapy of HLA-A2 ${ }^{+}$prostate cancer patients (Guise, 1997; Francini et al, 2002). In this study, we identified new PTHrP peptides that have the potential to generate prostate cancerspecific CTLs in HLA-A24 ${ }^{+}$prostate cancer patients, in order to extend the possibility of PTHrP peptide-based anticancer vaccine. We revealed that both the $\mathrm{PTHrP}_{36-44}$ and the $\mathrm{PTHrP}_{102-111}$ peptides have the potential to induce prostate cancer-reactive CTLs in HLA-A24 ${ }^{+}$prostate cancer patients. PBMCs from HLA$\mathrm{A}_{2}{ }^{+}$prostate cancer patients showed peptide-specific IFN- $\gamma$ production in six or seven of 10 patients when stimulated with the $\mathrm{PTHrP}_{102-110}$ and $\mathrm{PTHrP}_{36-44}$ peptide, respectively. More importantly, PBMCs that were stimulated with these PTHrP peptides showed cytotoxicity against prostate cancer cells in an HLA-A24restricted manner. These results indicate that these two PTHrP peptides are immunogenic, and therefore potentially useful for the specific immunotherapy of HLA-A24 ${ }^{+}$prostate cancer patients with metastases.

The $\mathrm{PTHrP}_{36-44}$ and the $\mathrm{PTHrP}_{102-110}$ peptides also induced peptide-specific and tumour-reactive CTLs from the PBMCs of
HLA-A24 ${ }^{+}$healthy donors. This result is consistent with that of a previous report demonstrating the induction of $\mathrm{PTHrP}$ peptidespecific CTLs from the PBMCs of HLA-A2 ${ }^{+}$healthy donors (Francini et al, 2002). As the $\mathrm{PTHrP}_{36-44}$ peptide shares three amino acids with $\mathrm{PTH}$, and because there is no homology between the PTHrP $\mathrm{P}_{102-111}$ peptide and PTH, crossreactivity between the PTHrP peptides and PTH could be excluded. Low levels of PTHrP have been sporadically detected in keratinocytes, uterus, and mammary glands during lactation (Tian et al, 1993). Recent advances in tumour immunology have revealed that self-antigens on human cancer cells are the most prevalent antigens recognized by the immune system (Rosenberg, 1999; Renkvist et al, 2001). CTL precursors reactive to nonmutated self-antigens may circulate in the peripheral blood of both certain healthy donors and cancer patients.

Here, we investigated whether or not IgG against PTHrP peptides would be detectable in plasma from HLA-A2 $4^{+}$healthy donors and prostate cancer patients, because the antibodies against CTL epitope peptides had already been observed in certain cancer patients and healthy donors (Nakatsura et al, 2002; Ohkouchi et al, 2002). We also previously reported that IgG reactive to peptides derived from prostate-related antigens was frequently detectable in healthy donors and prostate cancer patients (Harada et al, 2003a; Kobayashi et al, 2003; Matsueda et al, 2004). In this study, IgG reactive to either the $\mathrm{PTHrP}_{102-111}$ peptide or $\mathrm{PTHrP}_{110-119}$ peptide was frequently detected in healthy donors as well as in prostate cancer patients. This means that the PTHrP $\mathrm{P}_{102-111}$ peptide was recognized by both the cellular and humoral immune systems. Although we do not yet have a clear understanding of the roles played by peptide-specific IgG in antitumour immune responses, our clinical trials revealed that a peptide vaccination frequently resulted in the induction of IgG reactive to the CTL epitope peptides which were administered (Noguchi et al, 2003; Tanaka et al, 2003). In addition, the induction of IgG reactive to the vaccinated peptides was positively correlated with longer survival of advanced lung cancer patients (Mine et al, 2003). As regards the use of a peptide vaccination in cases of gastric cancer, prolonged survival has been observed in patients showing not only cellular, but also humoral immune responses to vaccinated peptides (Sato et al, 2003). In addition, the induction of IgG reactive to the administered peptides was correlated with a clinical response among patients with recurrent gynecologic cancer (Tsuda et al, 2004). Furthermore, we recently analysed 113 vaccinated patients with various types of cancers, and revealed that the augmentation of peptide-specific IgG after peptide vaccination could be a laboratory marker for the prediction of prolonged survival in vaccinated cancer patients compared to the induction of peptide-specific CTLs or the delayed-type hypersensitivity test (Mine et al, 2004). Moreover, we recently observed that peptide vaccination with a 9-mer CTL epitope peptide could induce peptide-specific and HLA-DR-restricted $\mathrm{CD} 4{ }^{+} \mathrm{T}$ cells in vivo (Harada et al, 2004). As these findings provide circumstantial evidence, further clinical study is needed to 
A
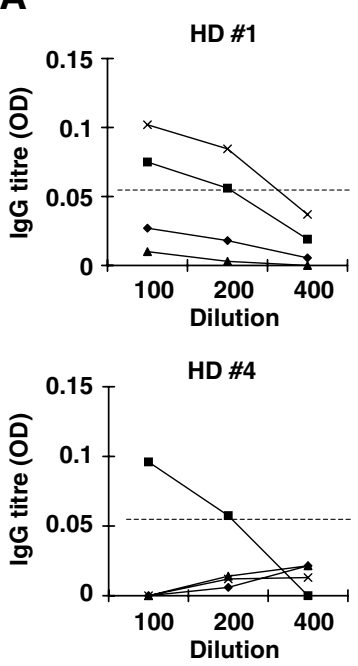

Pt \#1

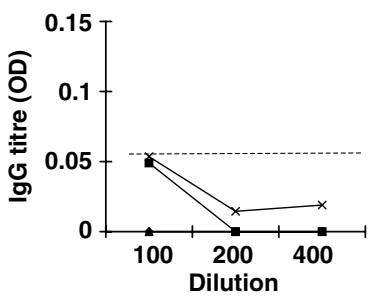

Pt \#4

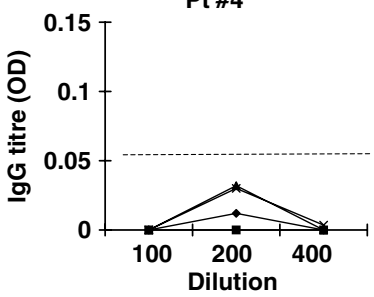

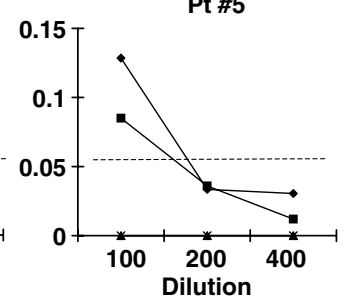

HD \#2

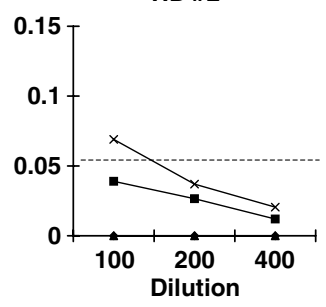

HD \#5

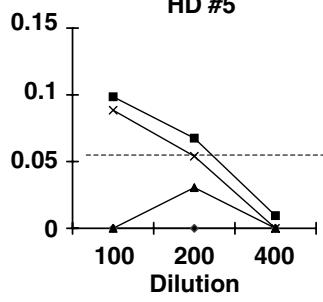

Pt \#2
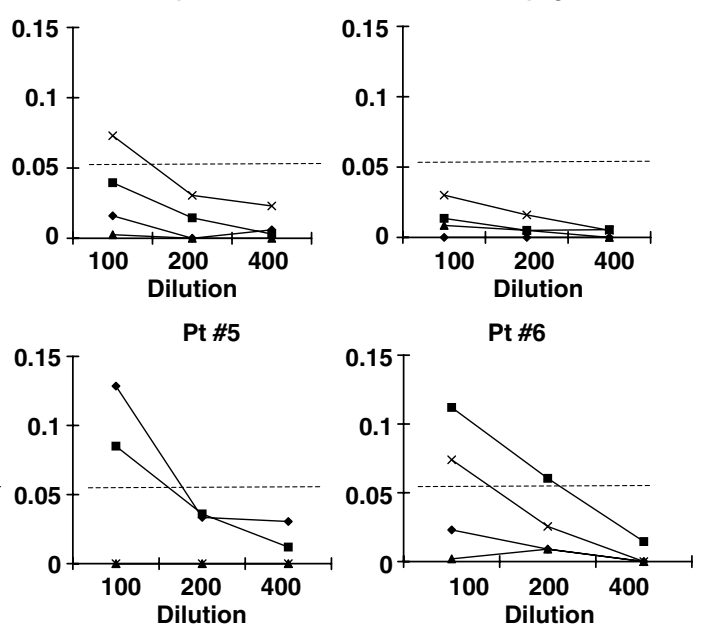

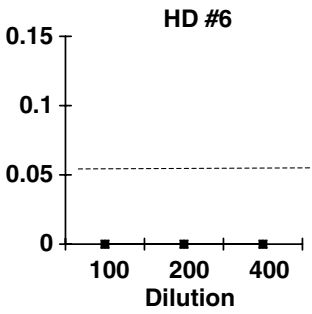

Pt \#3

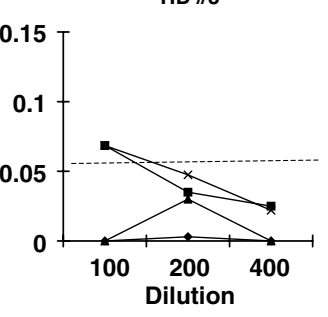

B

HD \#1 / anti-PTHrP 102-111
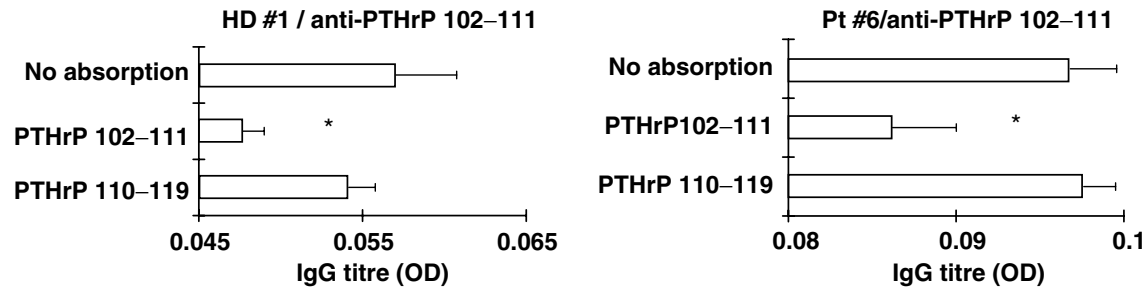

HD \#1/anti-PTHrP 110-119

Pt \#6/anti-PTHrP 110-119
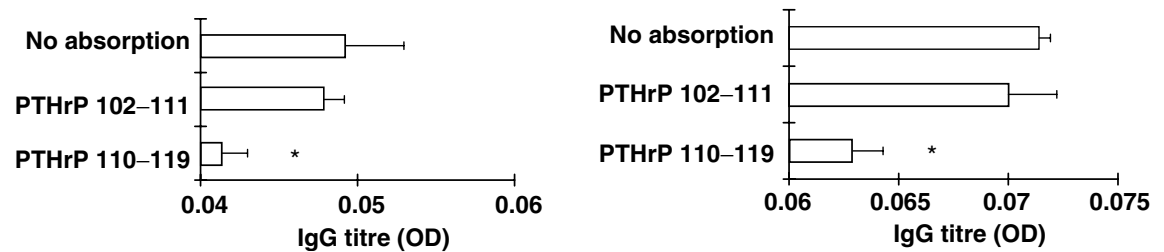

Figure 5 lgG reactive to the PTHrP peptides in plasma from healthy donors and prostate cancer patients. (A) Representative results from six healthy donors and six prostate cancer patients are shown. These values are shown as optical density (OD), and the responses to the HIV peptide were subtracted. IgG reactive to a corresponding PTHrP peptide was judged to be positive when the difference of the OD in I : I00-diluted plasma exceeded 0.05. The cutoff level (OD: 0.05) was determined based on the levels of anti-HIV peptide lgG in HIV-negative healthy donors. (B) To confirm the specificity of IgG to the indicated PTHrP peptides, $100 \mu$ l of sample plasma from either HD \# I and Pt \#6 was cultured in a plate precoated with either a corresponding PTHrP peptide or an irrelevant PTHrP peptide. Thereafter, the levels of IgG reactive to the PTHrP $102-111$ peptide or the PTHrP $110-119$ peptide in the resultant samples were determined by ELISA. 
elucidate the role and meaning of peptide-specific IgG in anticancer immunotherapy.

In conclusion, we identified new two PTHrP-derived peptides that are immunogenic in HLA-A2 $4^{+}$prostate cancer patients. The frequencies of the HLA-A24 allele are relatively high throughout the world (Imanishi et al, 1992). The information provided here might increase the possibility of treating HLA-A24 ${ }^{+}$prostate cancer patients with metastases using peptide-based immunotherapy.

\section{ACKNOWLEDGEMENTS}

This study was supported in part by a Grants-in-Aid for Cancer Research (15-17) from the Ministry of Health, Labor and Welfare of Japan, and Grants-in Aid from the Ministry of Education, Science, Sports and Culture of Japan. We thank Dr Masafumi Takiguchi of Kumamoto University for kindly providing C1R-A24 cells.

\section{REFERENCES}

Boon T, Coulie PG, Van den Eynde B (1997) Tumor antigens recognized by T cells. Immunol Today 81: $267-268$

Francini G, Scardino A, Kosmatopoulos K, Lemonnier F, Campoccia G, Sabatino M, Pozzessere D, Petrioli R, Lozzi L, Neri P, Fanetti G, Cusi GM, Correale P (2002) High-affinity HLA-A(*)02.01 peptides from parathyroid hormone-related protein generate in vitro and in vivo antitumor CTL response without autoimmune side effects. J Immunol 169: 4840 - 4844

Greenlee RT, Murray T, Bolden S, Wingo PA (2000) Cancer statistics 2000. CA Cancer I Clin 50: 7-33

Guise TA (1997) Parathyroid hormone-related protein and bone metastases. Cancer 80: $1572-1580$

Gulley J, Chen AP, Dahut W, Arlen PM, Bastian A, Steinberg SM, Tsang K, Panicali D, Poole D, Schlom J, Hamilton MJ (2002) Phase I study of a vaccine using recombinant vaccinia virus expressing PSA (rV-PSA) in patients with metastatic androgen-independent prostate cancer. Prostate 53: $109-117$

Harada M, Gohara R, Matsueda S, Muto A, Oda T, Iwamoto Y, Itoh K (2004) In vivo evidence that peptide vaccination can induce HLA-DRrestricted $\mathrm{CD} 4{ }^{+} \mathrm{T}$ cells reactive to a class I tumor peptide. J Immunol 172: $2659-2667$

Harada M, Kobayashi K, Matsueda S, Nakagawa M, Noguchi M, Itoh K (2003a) Prostate-specific antigen-derived epitopes capable of inducing cellular and humoral responses in HLA-A24 ${ }^{+}$prostate cancer patients. Prostate 57: $152-159$

Harada M, Noguchi M, Itoh K (2003b) Target molecules in specific immunotherapy against prostate cancer. Int J Clin Oncl 8: 193-199

Hida N, Maeda Y, Katagiri K, Takasu H, Harada M, Itoh K (2002) A new culture protocol to detect peptide-specific cytotixic $\mathrm{T}$ lymphocyte precursors in the circulation. Cancer Immunol Immunother 51: 219-228

Imanishi T, Akazawa T, Kimura A (1992) Allele and haplotype frequencies for HLA and complement loci in various ethnic groups. In HLA 1991, Tsuji K, Aizawa M, Sasazuki T (eds). Vol. 1, pp 1065-1220. Oxford: Oxford Scientific Publications

Inoue Y, Takaue Y, Takei M, Kato K, Kanai S, Harada Y, Tobisu K, Noguchi M, Kakizoe T, Itoh K, Wakasugi H (2001) Induction of tumor specific cytotoxic $\mathrm{T}$ lymphocytes in prostate cancer using prostatic acid phosphatase derived HLA-A2402 binding peptide. J Urol 166: 1508 - 1513

Juppner H, Abou-Samra AB, Freeman M, Kong XF, Schipani E, Richards J, Kolakowski LF, Hock J, Potts JT, Kronenberg HM, Serge GV (1991) AG protein-linked receptor for parathyroid hormone and parathyroid hormone-related protein. Science 254: 1024-1026

Kobayashi K, Noguchi M, Itoh K, Harada M (2003) Identification of a prostate-specific membrane antigen-derived peptide capable of eliciting both cellular and humoral immune responses in HLA-A $24^{+}$prostate cancer patients. Cancer Sci 94: 622-627

Marchand M, van Baren N, Weynants P, Brichard V, Dréno B, Tessier MH, Rankin E, Parmiani G, Arienti F, Humblet Y, Bourlond A, Vanwijck R, Liénard D, Beauduin M, Dietrich PY, Russo V, Kerger J, Masucci G, Jäger E, De Greve J, Atzpodien J, Brasseur F, Coulie PG, van der Bruggen P, Boon T (1999) Tumor regressions observed in patients with metastatic melanoma treated with an antigenic peptide encoded by gene MAGE-3 and presented by HLA-A1. Int J Cancer 80: 219-230

Matsueda S, Kobayashi K, Nonaka Y, Noguchi M, Itoh K, Harada M (2004) Identification of new prostate stem cell antigen-derived peptides immunogenic in HLA-A2 ${ }^{+}$patients with hormone-refractory prostate cancer. Cancer Immunol Immunother 53: 479-489

Mine T, Gouhara R, Hida N, Imai N, Azuma K, Rikimaru T, Katagiri K, Nishikori M, Sukehiro A, Nakagawa M, Yamada A, Aizawa H, Shirouzu $\mathrm{K}$, Itoh K, Yamana H (2003) Immunological evaluation of CTL precursor-oriented vaccines for advanced lung cancer patients. Cancer Sci 94: $548-556$
Mine T, Sato Y, Noguchi M, Sasatomi T, Gouhara R, Tsuda N, Katagiri K, Rikimaru H, Shichijo S, Kamura T, Hashimoto T, Shirouzu K, Yamda A, Todo S, Itoh K, Yamana H (2004) Humoral responses to peptides correlate with overall survival in advanced cancer patients vaccinated with peptides based on pre-existing, peptide-specific cellular responses. Clin Cancer Res 10: 929-937

Murphy G, Tjoa B, Ragde H, Kenny G, Boynton A (1996) Phase I clinical trial: T-cell therapy for prostate cancer using autologous dendritic cells pulsed with HLA-A0201-specific peptides from prostate-specific membrane antigen. Prostate 29: $371-380$

Murphy GP, Tjoa BA, Simmons SJ, Jarisch J, Bowes VA, Rogers M, Elgamal A, Kenny GM, Cobb OE, Ireton RC, Troychak MJ, Salgaller ML, Boynton AL (1999) Infusion of dendritic cells pulsed with HLA-A2-specific prostate-specific membrane antigen peptides: a phase II prostate cancer vaccine trial involving patients with hormone-refractory metastatic disease. Prostate 38: $73-78$

Nakatsura T, Senju S, Ito M, Nishimura Y, Itoh K (2002) Cellular and humoral immune responses to a human pancreatic cancer antigen, coactosin-like protein, originally defined by the SEREX method. Eur J Immunol 32: $826-836$

Nestle FO, Alijagic S, Gilliet M, Sun Y, Grabbe S, Dummer R, Burg G, Schadendorf D (1998) Vaccination of melanoma patients with peptideor tumor lysate-pulsed dendritic cells. Nat Med 4: 328-332

Noguchi M, Mine T, Suetsugu N, Tomiyasu K, Suekane S, Yamada A, Itoh K, Noda S (2003) Induction of cellular and humoral immune responses to tumor cells and peptides in HLA-A24 positive hormonerefractory prostate cancer patients by peptide vaccination. Prostate 57: $80-92$

Ohkouchi S, Yamada A, Imai N, Mine T, Harada K, Shichijo S, Maeda Y, Saijyo Y, Nukiwa T, Itoh K (2002) Non-mutated tumor rejection antigen peptides elicit type-I allergy in the majority of healthy individuals. Tissue Antigens 59: $259-272$

Parker KC, Bednarek MA, Coligan JE (1994) Scheme for ranking potential HLA-A2 binding peptides based on independent binding of individual peptide side-chains. J Immunol 152: 163-175

Philbrick WM, Wysolmerski JJ, Galbarith S, Holt E, Orloff J, Yang KH, Vasavada RC, Weir EC, Broadus AE, Stewart AF (1996) Defining the roles of parathyroid hormone related protein in normal physiology. Physiol Rev 76: $127-173$

Rammensee HG, Friege T, Stevanovics S (1995) MHC ligands and peptides motifs. Immunogenetics 41: $178-228$

Renkvist N, Castelli C, Robbins PF, Parmiani G (2001) A listing of human tumor antigens recognized by $\mathrm{T}$ cells. Cancer Immunol Immunother 50: $3-15$

Rosenberg SA (1999) A new era for cancer immunotheraphy based on the genes that encode cancer antigens. Immunity 10: 281-287

Rosenberg SA, Yang JC, Schwartzentruber DJ, Hwu P, Marincola FM, Topalian SL, Restifo NP, Dudley ME, Schwarz SL, Spiess PJ, Wunderlich JR, Prkhurst MA, Kawakami Y, Seipp CA, Einhorn JH, White DE (1998) Immunologic and therapeutic evaluation of a synthetic peptide vaccine for the treatment of patients with metastatic melanoma. Nat Med 4: $321-327$

Sanders LJ, Chattopadhyay N, Kifor O, Yamaguchi T, Brown ME (2001) $\mathrm{Ca}^{2+}$-sensing receptor expression and PTHrP secretion in PC-3 human prostate cancer cells. Am J Physiol Endocrinol Metab 281: $1267-1274$

Sato Y, Shomura H, Maeda Y, Mine T, Ueno Y, Akasaka Y, Kondo M, Takahashi S, Shinohara T, Katagiri K, Sato M, Okada S, Matsui K, Yamada A, Yamana H, Itoh K, Todo S (2003) Immunogical evaluation of peptide vaccination for patients with gastric cancer based on pre-existing cellular response to peptide. Cancer Sci 94: 802 - 808 
Small EJ, Fratesi P, Reese DM, Strang G, Laus R, Peshwa MV, Valon FH (2000) Immunotherapy of hormone-refractory prostate cancer with antigen-loaded dendritic cells. J Clin Oncol 18: 3894-3903

Suva LJ, Winslow GA, Wettenhall REH, Hammonds RG, Moseley JM, Diefenbach-Jagger H, Rodda CP, Kemp BE, Rodriguez H, Chen EY, Hudson PJ, Martin TJ, Wood WI (1987) A parathyroid hormone-related protein implicated in malignant hypercalcemia: cloning and expression. Science 237: 893-896

Tanaka S, Harada M, Mine T, Noguchi M, Gohara R, Azuma K, Tamura M, Yamada A, Morinaga A, Nishikori M, Katagiri K, Itoh K, Yamana $\mathrm{H}$, Hashimoto T (2003) Peptide vaccination for patients with melanoma and other types of cancer based on pre-existing peptide-specific cytotoxic $\mathrm{T}$ lymphocyte precursors in the periphery. J Immunother 26: 357-366
Tian J, Smogorzewski M, Kedes L, Massry SG (1993) Parathyroid hormone-parathyroid hormone-related protein receptor messenger RNA is present in many tissues besides the kidney. Am J Nephrol 13: $210-213$

Tjoa BA, Simmons SJ, Bowes VA, Ragde H, Rogers M, Elgamal A, Kenny GM, Cobb OE, Ireton RC, Troychak MJ, Salgaller ML, Boynton AL, Murphy GP (1998) Evaluation of phase I/II clinical trials in prostate cancer with dendritic cells and PSMA peptides. Prostate 36: $39-44$

Tsuda N, Mochizuki K, Harada M, Sukehiro A, Kawano K, Yamada A, Ushijima K, Sugiyama T, Nishida T, Yamana H, Itoh K, Kamura T (2004) Vaccination with pre-designated or evidence-based peptides for patients with recurrent gynecologic cancers. J Immunother 27: 60-72 